\title{
Erratum to: The vertebrate muscle Z-disc: sarcomere anchor for structure and signalling
}

\author{
Pradeep K. Luther
}

Published online: 15 January 2011

(C) Springer Science+Business Media B.V. 2011

Erratum to: J Muscle Res Cell Motil (2009) 30:171-185 DOI 10.1007/s10974-009-9189-6

In transverse view, striated muscle Z-disc has two characteristic patterns which are referred to as basketweave and small-square. Previous studies (referenced in the review) have shown that the transition from small-square to basketweave is accompanied by an increase in lattice size of $20 \%$. In the above review this was stated incorrectly as a decrease of $20 \%$. The author apologises for this error.

The online version of the original article can be found under doi: 10.1007/s10974-009-9189-6.

P. K. Luther $(\bowtie)$

Molecular Medicine Section, National Heart and Lung Institute, Imperial College London, London SW7 2AZ, UK

e-mail: p.luther@imperial.ac.uk 